Original Research Paper

\title{
Implementasi Pembelajaran Lesson Study Pada Matakuliah Genetika
}

\author{
Mahrus $^{1 *}$, Lalu Zulkifli1, Syachruddin $\mathbf{A R}^{1}$ \\ ${ }^{1}$ Program Studi Pendidikan Biologi Fakultas Keguruan dan Ilmu Pendidikan Universitas Mataram, Indonesia;
}

\author{
Article history \\ Received: November $12^{\text {th }} 2018$ \\ Revised: April $5^{\text {th }} 2019$ \\ Accepted: April 29th 2019 \\ *Mahrus: Program Studi \\ Pendidikan Biologi Fakultas \\ Keguruan dan Ilmu Pendidikan \\ Universitas Mataram, Indonesia; \\ Email: mahrus@unram.ac.id
}

\begin{abstract}
The purpose of this study was to improve the results and learning process of Genetic subjects in the Biology Education Study Program through lesson study (LS). The research type is descriptive, the sampling technique used purposive. The study sample used 40 students in the sixth semester of the class a Biology Education Study Program, Faculty of Education, the University of Mataram in academic year 2017/2018. The research data collection technique used observation, documentation, and tests. Data on student learning outcomes and LSbased learning processes were analyzed descriptively. LS implementation in this study consisted of four cycles and each cycle consisted of three stages, namely: planning, implementation, and reflection. Classically the average value of students' cognitive achievement is $82.1 \%$ in cycle I and II while in cycle III and IV it increases to $82.67 \%$. Data from LS implementation observation results obtained an average value of $91.63 \%$. The conclusion of this study is the application of LS learning can improve student achievement and learning processes on Genetic subjects in the Biology Education Study Program. It is recommended to other researchers to conduct similar follow-up research in broader research areas, more samples, use more complex research designs, and use more subjects so that more optimal results can be found.
\end{abstract}

Keywords: Lessons Study; learning; genetics; learning achievements; collaborative

Abstrak: Tujuan penelitian ini adalah untuk meningkatkan hasil dan proses pembelajaran mata kuliah Genetika di Program Studi Pendidikan Biologi melalui lesson study (LS). Jenis penelitian ini adalah deskriptif dengan menggunakan 40 orang mahasiswa semester enam kelas a Program Studi Pendidikan Biologi Fakultas Ilmu Pendidikan Universitas Mataram tahun akademik 2017/2018. Teknik pengambilan sampel menggunakan purposive, dan teknik pengumpulan menggunakan observasi, dokumentasi, dan tes. Data hasil belajar mahasiswa dan proses pembelajaran berbasis LS dianalisis secara deskriptif. Implementasi LS dalam penelitian ini terdiri dari empat siklus dan setiap siklus terdiri dari tiga tahap, yaitu: perencanaan, implementasi, dan refleksi. Secara klasikal nilai rata-rata hasil belajar kognitif mahasiswa adalah $82,1 \%$ pada siklus I dan II sedangkan pada siklus III dan IV meningkat menjadi $82,67 \%$. Data hasil observasi implementasi LS diperoleh nilai rata-rata $91,63 \%$. Kesimpulan dari hasil penelitian ini adalah penerapan pembelajaran LS dapat meningkatkan hasil dan proses belajar mahasiswa pada mata kuliah Genetika di Program Studi Pendidikan Biologi. Disarankan kepada peneliti lain untuk melakukan penelitian lanjutan yang sejenis pada wilayah penelitian yang lebih luas, sampel yang lebih banyak, menggunakan rancangan penelitian yang lebih kompleks, dan menggunakan mata pelajaran lebih banyak lagi sehingga dapat ditemukan hasil yang lebih optimal.

Kata kunci: Lessons Study; pembelajaran; genetika; hasil belajar; kolaboratif. 


\section{Pendahuluan}

Lesson Study (LS) merupakan salah satu model pembinaan profesi pendidik melalui pengkajian pembelajaran secara kolaboratif dan berkesinambungan dengan berlandaskan prinsipprinsip kolegalitas dan mutual learning untuk membangun komunitas belajar mengajar (Perry $d k k$., 2009). Selanjutnya dikatakan bahwa pembelajaran LS memiliki beberapa ciri, yaitu: (1) tujuan bersama untuk jangka panjang yang dibuat dan disepakati oleh tim teaching yang ingin ditingkatkan dalam kurun waktu jangka panjang dengan cakupan tujuan yang lebih luas; (2) materi pelajaran yang sulit, artinya bahwa dosen mengutamakan pada materi kuliah yang dianggap menjadi titik lemah dalam pembelajaran mahasiswa yang sangat sulit untuk dipelajari; (3) pengembangan pembelajaran yang dilakukan mahasiswa terutama terkait dengan minat dan motivasinya dalam mengikuti proses pembelajaran; (4) observasi pembelajaran secara langsung dengan tujuan untuk menilai kegiatan pengembangan dan pembelajaran yang dilaksanakan serta mengamati proses pembelajaran secara langsung sehingga data yang diperoleh akan lebih akurat dan utuh.

Genetika adalah suatu ilmu yang mempelajari tentang keturunan. Genetika sebagai suatu disiplin ilmu kaya akan sejarah penemuan dan investigasi mulai dari berbagai molekul (protein, DNA dan RNA), sel, organisme, dan populasi, melalui berbagai pendekatan penelitian. Tidak hanya informasi genetik yang berperan sebagai significant role selama evolusi, tetapi juga pengaruh ekspresi dari peran individual di semua level.

Beberapa hasil penelitian pembelajaran genetika mulai dari SMA sampai perguruan tinggi mendapatkan berbagai masalah seperti: mayoritas mahasiswa menganggap genetika sebagai matakuliah yang abstrak, rumit, dan menegangkan sehingga tidak bermakna dalam kehidupan seharihari, sehingga tingkat pemahaman mahasiswa pada konsep genetika masih lebih banyak yang mengalami miskonsepsi (Duncan dan Reiser, 2007; Mustika dkk., 2014; Wahyono $d k k ., 2016$ ).

Kompetensi mata kuliah genetika menekankan pada penguasaan bagaimana gen mahluk hidup itu diekspresikan. Pengetahuan teoritis dan kemampuan aplikatif dalam membuat inovasi yang terkait dengan pembelajaran genetika dalam upaya pencapaian kompetensi tersebut, maka perlu dirancang suatu pembelajaran yang berpusat pada mahasiswa yaitu melalui pembelajaran kolaboratif. Ueno (2013) menegaskan bahwa pembelajaran kolaboratif dapat memberi kesempatan kepada peserta didik untuk berpartisipasi aktif dan saling belajar di antara mereka untuk membangun pengetahuan sendiri melalui diskusi dan kolaborasi. Pembelajaran ini menitikberatkan pada kerjasama antar mahasiswa yang didasarkan pada konsensus yang dibangun sendiri oleh anggota kelompok. Salah satu manfaat dari pembelajaran menggunakan pendekatan kolaboratif adalah meningkatkan kualitas pembelajaran baik dari segi pencapaian hasil belajar mahasiswa maupun dari segi teknis pembelajaran yang lebih nyaman dan penuh kreativitas (Wahyono $d k k$., 2016).

Berdasarkan beberapa uraian dan penjelasan yang dipaparkan oleh para pakar, maka sesungguhnya LS merupakan penelitian atau pengkajian terhadap pembelajaran secara komprehensif meliputi: pembinaan profesi, pengkajian pembelajaran, kolaboratif, berkelanjutan, kolegalitas, mutual learning, dan komunitas belajar (Hendayana, 2007). Dari semua uraian diatas, tampak bahwa betapa pentingnya penerapan pembelajaran LS menggunakan pendekatan kolaboratif sebagai upaya meningkatkan aktivitas belajar mahasiswa dan meningkatkan profesionalisme tenaga pengajar, karena itu penelitian ini penting dilakukan.

\section{Metode}

Penelitian ini merupakan penelitian deskriptif dengan subjek penelitian berjumlah 40 orang mahasiswa kelas A semester VI program studi Pendidikan Biologi FKIP Universitas Mataram. Data pengamatan diperoleh melalui lembar pengamatan keterlaksanaan lesson study dan capaian kognitif mahasiswa. Pengamatan dilakukan oleh observer (dosen dan mahasiswa) untuk memperoleh informasi kesiapan pembelajaran mahasiswa keaktifan dalam kegiatan diskusi serta perbaikan-perbaikan yang dapat dilakukan pada pertemuan selanjutnya. Pada setiap akhir putaran dilakukan identifikasi terhadap keterlaksanaan lesson study dan ketercapaian pembelajaran yang ditunjukkan oleh penilaian kognitif mahasiswa.

Data pelaksanaan LS dan data hasil belajar kognitif mahasiswa pada mata kuliah Genetika dianalisis secara deskriptif. Untuk mengetahui seberapa besar peningkatan kemampuan kognitif mahasiswa digunakan analisis statistika dengan menghitung nilai gain yang dinormalisasi (g), merupakan peningkatan kemampuan mahasiswa setelah pembelajaran. 


\section{Skor postes-skor pretes \\ $\mathrm{g}=\frac{}{\text { Skor maksimal-skor pretes }}$ (Archambault, 2008)}

Hasil perhitungan $\mathrm{N}$-gain tersebut kemudian dikategorikan kedalam 3 kategori yaitu (Archambault, 2008) :

Tinggi : N-gain $>0.7$,

Sedang : $0.3 \leq \mathrm{N}$-gain $\geq 0.7$,

Rendah : N-gain $<0.3$.

\section{Hasil dan Pembahasan}

Pengembangan kegiatan scientific dalam penelitian ini dapat dianalisis melalui keterlaksanaan LS pada setiap putaran dan kenaikan hasil belajar mahasiswa dalam periode tersebut. Dalam pelaksanaannya, putaran I dan II dilakukan sebelum ujian tengah semester sedangkan putaran III dan IV dilaksanakan setelah ujian tengah semester. Keterlaksanaan LS dalam periode tersebut diperoleh melalui lembar pengamatan keterlaksanaan LS yang diisi oleh observer. Berikut hasil keterlaksanaan LS dijelaskan pada Tabel 1.

Tabel 1. Presentase respon positif pengamat (observer) terhadap LS

\begin{tabular}{lll}
\hline Tahapan & Rata-rata & Kualifikasi \\
\hline Plan & 92,23 & Sangat Baik \\
Do & 88,42 & Baik \\
See & 94,24 & Sangat Baik \\
Rerata & 91,63 & Sangat Baik \\
\hline
\end{tabular}

Berdasarkan data pada Tabel 1 dapat dideskripsikan bahwa persentase rata-rata observer yang memberikan respon postif terhadap LS adalah 91,63\%. Artinya bahwa kualitas pelaksanaan LS di Program Studi Pendidikan Biologi FKIP Unram tergolong sangat baik. Selanjutnya pada Tabel 2 ditampilkan hasil belajar kognitif 40 orang mahasiswa progam studi Pendidikan Biologi Kelas A Semester VI.

Tabel 2. Hasil belajar kognitif 40 orang mahasiswa

\begin{tabular}{|c|c|c|c|c|}
\hline \multirow{2}{*}{\multicolumn{2}{|c|}{ Keberhasilan Kelas }} & & \multicolumn{2}{|c|}{ Perolehan hasil belajar mahasiwa } \\
\hline & & & Putaran I \& II & Putaran III \& IV \\
\hline $\begin{array}{l}\text { Rata-rata } \\
\text { (LS) }\end{array}$ & kelas & $\mathrm{A}$ & 80,12 & 82,67 \\
\hline $\begin{array}{l}\text { Rata-rata } \\
\text { (kontrol) }\end{array}$ & kelas & $\mathrm{B}$ & 75,15 & 78,14 \\
\hline
\end{tabular}

Data pada Tabel 2 menunjukkan bahwa pembelajaran genetika berbasis LS dapat meningkatkan hasil belajar kognitif mahasiswa. Paparan dan analisis data putaran I dan II menunjukkan bahwa secara klasikal rata-rata kognitif mahasiswa kelas A sebagai kelas eksperimen sebesar 82,1\% sedangkan kelas B sebagai kelas kontrol sebesar 75,15. Selanjutya pada putaran III dan IV tampak bahwa perolehan rata-rata hasil belajar kognitif mahasiswa meningkat sebesar $82,67 \%$.

Hasil penelitian ini hampir sama dengan hasil penelitian yang dilaporkan oleh sejumlah peneliti sebelumnya yang pada intinya melaporkan bahwa implementasi LS dapat meningkatkan hasil belajar kognitif mahasiswa, bahkan mencapai angka di atas 80\%, (Wahyono $d k k ., 2016$; Upayogi, 2017). Hasil penelitian ini dipertegas lagi oleh Sumarni (2008), bahwa kegiatan LS harus mengalami manfaat oleh dosen, karena itu dari hasil yang diperoleh disarankan bahwa LS akan diterapkan secara berkelanjutan dan kolaboratif, sehingga peserta LS mendapatkan berbagai manfaat seperti penguatan kolegialitas dan penguatan aktivitas pembelajaran sehari-hari yang terkait dengan tujuan jangka panjang. Hal yang sama juga dilaporkan oleh Andini $d k k$. (2016), bahwa penggunaan LS dalam pembelajaran dapat meningkatkan peningkatan kualitas proses dan kemandirian belajar mahasiswa. Selain itu pembelajaran berbasis LS mampu mengembangkan kemandirian belajar karakter (Chandrasar $d k k .$, 2015).

Meskipun hasil penelitian ini tergolong berhasil, namun berdasarkan data hasil belajar yang didapatkan, masih ada mahasiswa yang memiliki hasil belajar kognitif pada kisaran yang rendah. Dalam situasi pembelajaran berikutnya mahasiswa tersebut mampu memberdayakan hasil belajar melalui kegiatan pembelajaran yang didesain secara menarik melalui LS. Hasanah (2012) menyatakan bahwa hasil belajar merupakan kemampuan aktual yang dapat diukur dan berwujud pada penguasaan ilmu pengetahuan, sikap keterampilan, dan nilainilai yang dicapai oleh mahasiswa sebagai hasil dari proses belajar.

Berdasarkan perhitungan rata-rata skor Gain (N-Gain) ternormalisasi hasil belajar mahasiswa adalah 0,767 , dapat dimaknai bahwa efektivitas pelaksanaan LS terhadap hasil belajar mahasiswa di Program Studi Pendidikan Biologi masuk kualifikasi tinggi atau sangat baik.

Kualitas pelaksanaan penelitian yang sangat baik tersebut memberikan efektivitas terhadap kompetensi profesional dosen dan hasil belajar mahasiswa dengan kualifikasi tinggi. Hal ini 
menunjukkan bahwa secara deskriptif pembelajaran LS efektif dalam meningkatkan kompetensi profesional dosen dan hasil belajar mahasiswa pada mata kuliah Genetika di Program Studi Pendidikan Biologi FKIP Unram.

Pada Tabel 3 ditampilkan hasil pelaksanaan LS yang menggambarkan keterlaksanaan LS pada siklus I, II, III dan siklus IV.

Tabel 3. Persentase keterlaksanaan LS pada empat putaran

\begin{tabular}{lll}
\hline $\begin{array}{l}\text { Hasil Peaksanaan } \\
\text { LS }\end{array}$ & $\begin{array}{l}\text { Keterlaksanaan } \\
\text { LS }\end{array}$ & $\begin{array}{l}\text { Ketidakterlaksa- } \\
\text { naan LS }\end{array}$ \\
\hline Putaran I dan II & 88,24 & 11,76 \\
Putaran II dan IV & 95,02 & 4,98 \\
Rata-rata & 91,63 & 8,37 \\
\hline
\end{tabular}

Keterlaksanaan LS diperoleh melalui pengamatan pada setiap pertemuan, meliputi tahap plan, do, dan tahap see. Pada putaran I dan II, persentase keterlaksanaan LS sebesar 88,24\% (terlaksana). Persentase itu diperoleh karena tidak semua indikator yang diamati muncul pada saat kegiatan, baik pada tahap plan, do, maupun see. Salah satu indikator yang tidak muncul adalah penyusunan RPP dan instrumen penelitian oleh tim dosen. Pada putaran III dan IV, persentase keterlaksanaan LS yang diperoleh mengalami peningkatan menjadi $95.02 \%$. Jika nilai persentase tersebut dirata-ratakan maka didapatkan nilai ratarata keterlaksaan LS sebesar 91,63\%.

Beberapa hasil penelitian sebelumnya melaporkan hasil yang sama dengan hasil penelitian ini yaitu keterlaksanaan LS sangat baik karena mencapai nilai rata-rata keterlaksanaan lebih dari 90\%, dan LS mampu meningkatan kualitas proses dan kemandirian belajar mahasiswa, meningkatkan mutu proses dan hasil pembelajaran, meningkatan kemampuan guru menerapkan pendekatan saintifik, dan mengembangkan karakter kemandirian belajar siswa (Sumarni, 2008; Chandrasar dkk., 2015; Andini $d k k .$, 2016; Wahyono $d k k .$, 2016; Upayogi, 2017).

\section{Kesimpulan}

Berdasarkan hasil dan pembahasan serta tidak terlepas dari permasalahan penelitian yang dikaji, dapat disimpulkan bahwa implementasi pembelajaran lesson study dapat meningkatkan hasil dan proses pembelajaran mahasiswa pada mata kuliah Genetika di Program Studi Pendidikan Biologi FKIP Universitas Mataram.

\section{Daftar Pustaka}

Andini, T. M., E. Wahyuni, S. Prastiyowati. 2016. Implementasi Lesson Study untuk peningkatan kualitas proses dan kemandirian belajar mahasiswa. JINoP Jurnal Inovasi Pembelajaran, 2 (1): 303308.

Archambault, J. 2008. The Effect of Developing Kinematics Concepts Graphically Prior to Introducing Algebraic Problem Solving Techniques. Action Research Required for the Master of Natural Science Degree with Concentration in Physics; Arizona State University.

Chandrasar, T. R., D. Trapsilasiwi, D. Kurniati. 2015. Implementasi pembelajaran berbasis lesson study untuk mengembangkan karakter kemandirian belajar siswa kelas VII C SMP Negeri 9 Jember semester genap tahun ajaran 2013/2014 pada sub pokok bahasan Garis dan Sudut. Kadikma, 6 (2): 109-118.

Duncan, R. G dan B. J. Reiser. 2007. Reasoning across ontologically distinct levels: students' understandings of molecular genetics. Journal of Research in Science Teaching, 44(7): 938-959.

Hasanah, N. 2012. Pengaruh Pembelajaran Problem-Based Learning Melalui Strategi Belajar Review, Question, Read, Reflect, Recite, \& Review Terhadap Kemampuan Berpikir Kritis, Hasil Belajar Kognitif dan Hasil Belajar Afektif Siswa Kelas VII SMPN 18 Balikpapan. Tesis, tidak dipublikasi. Malang: PPS-Universitas Negeri Malang.

Hendayana, S. 2007. Lesson Study: Suatu Strategi untuk Meningkatkan Keprofesionalan Pendidik. UPI Press.

Mulyana, S. 2007. Lesson Study (Makalah). LPMPJawa Barat, Kuningan

Mustika, A. A., Y. Hala, A. F. Arsal. 2014. Identifikasi Miskonsepsi Mahasiswa Biologi Universitas Negeri Makassar pada Konsep Genetika dengan Metode CRI Identification of Misconception of Biology Students at State University of Makassar on Genetic Concept by Applying CRI Method. Sainsmat, III (2): 122-129.

Perry, R., C. Lewis, S. Friedkin, dan E. Baker. 2009. Teachers' Knowledge Development during Lesson Study: Impact of ToolkitSupported Lesson Study on Teachers' 
Knowledge of Mathematics for Teaching. Paper presented at AERA. March 24, 2009, San Diego.

Sumarni, W. 2008. Lesson Study untuk meningkatkan mutu proses dan hasil pembelajaran perkuliahan Dasar Pemisahan Analitik. Jurnal Inovasi Pendidikan Kimia, 2 (1): 209-215.

Ueno, M. 2013. Pembelajaran Kolaboratif dan Pendidikan Demokrasi. Makalah Disajikan pada Short-Term Training on Lesson Study (STOLS) for Institute of Teacher Training and Education Personnel (ITTEP), Tokyo, 14 Oktober-8 November.

Upayogi, N. T. 2017. Peningkatan kemampuan guru menerapkan pendekatan saintifik melalui lesson study. Jurnal PINUS, 2 (2): 102-112.

Wahyono, P., I. Hindun, Muizzudin, F. J. Miharja. 2016. Implementasi Pembelajaran Lesson Study Pada Matakuliah Genetika Lanjut. Jurnal Inovasi Pembelajaran, 2 (2): 400406. 